\title{
GMR
}

\section{Dynamic relationship between SIPA1 gene and protein expression and the development of gastric cancer}

\author{
J.Y. Li ${ }^{1 *}$, J.B. Wang ${ }^{2 *}$, C.B. Liu ${ }^{2}$, D.L. $\mathrm{Ma}^{1}$ and J.H. $\mathrm{Ma}^{3}$ \\ ${ }^{1}$ Department of Medical Oncology, Linyi Central Hospital, Linyi, Shandong, \\ China \\ ${ }^{2}$ Department of General Surgery, Linyi Central Hospital, Linyi, Shandong, \\ China \\ ${ }^{3}$ Department of General Surgery, Yishui County People's Hospital, Linyi, \\ Shandong, China \\ *These authors contributed equally to this study. \\ Corresponding author: J.H. Ma \\ E-mail: germanywork@163.com \\ Genet. Mol. Res. 16 (1): gmr16019271 \\ Received September 13, 2016 \\ Accepted December 9, 2016 \\ Published March 16, 2017 \\ DOI http://dx.doi.org/10.4238/gmr16019271 \\ Copyright $(2017$ The Authors. This is an open-access article distributed under the terms of \\ the Creative Commons Attribution ShareAlike (CC BY-SA) 4.0 License.
}

ABSTRACT. Association of signal-induced proliferation-associated 1 (SIPA) gene and protein expression with gastric cancer development was examined. SIPA1 mRNA and protein levels were determined by real-time quantitative polymerase chain reaction and western blot, respectively, in 40 gastric tumor and tumor-adjacent normal tissues. SIPA1, VEGF-A, and FVIII levels in 60 gastric tumor and 40 tumoradjacent normal tissues were examined by immunohistochemical staining. Correlations between SIPA1, VEGF-A, and microvessel density (MVD) were analyzed. SIPA1 mRNA levels were significantly lower in tumor tissues than in tumor-adjacent normal tissues $(\mathrm{P}<$ 0.05). Similarly, protein levels were significantly lower in tumor tissues $(0.3043 \pm 0.1062)$ than in tumor-adjacent normal tissues

Genetics and Molecular Research 16 (1): gmr16019271 
$(0.5423 \pm 0.0682, \mathrm{P}<0.05)$. Positive staining rates of SIPA1 $(48.3 \%)$ and VEGF-A (36.7\%) were lower and higher, respectively, in tumor tissues than in tumor-adjacent normal tissues ( 65.0 and $2.5 \%, \mathrm{P}<0.05$ ). Positive protein staining rates in tumor tissues correlated with the degree of differentiation, lymph node metastases, and clinical grading $(P<0.05)$ and not with sex, age, or tumor size $(P>0.05)$. Significantly higher MVD $(57.4 \pm 9.3)$ was observed in tumor tissues displaying positive SIPA1 staining than in tumor-adjacent normal tissues (41.2 \pm 5.7, $\mathrm{P}<0.05$ ). SIPA1 and VEGF-A expression in tumor tissues were negatively correlated $(\mathrm{r}=-0.736, \mathrm{P}<0.05)$. SIPA1 and its protein may play important roles in gastric cancer invasion, metastasis, and biological behavior. Low SIPA1 levels in gastric cancer may accelerate tumor development and progression by promoting VEGF-A expression to increase vascular density.

Key words: SIPA1; Gastric cancer; VEGF-A; Microvessel density

\section{INTRODUCTION}

The mortality rate of gastric cancer remains relatively high since early stage gastric cancer has no clear symptoms, making early detection and diagnosis difficult. Most patients already progress to the advanced stages of gastric cancer at the time of diagnosis (Hamashima et al., 2015). Studies have shown that the median survival time of late-stage gastric cancer patients is only 7-11 months (Tanaka et al., 2011). Since both genetic and environmental factors are important contributors to the development of gastric cancer (Nadauld and Ford, 2013), cancers are in fact multifactorial disorders. Recent studies on gastric cancer invasion and metastasis genes have also confirmed that several genes, including P16, COX2, BMI1, and HER-2, play important roles in the tumorigenesis, development, and prognosis of gastric cancer (Hsieh et al., 2009; Kim and Zhang, 2013; Li et al., 2016). It has been reported that SIPA1 is a candidate tumor metastasis efficiency-modifying gene that is closely associated with the occurrence and development of epithelial tumors (Süllner et al., 2012). Currently, there are very few reports on the dynamic relationship between SIPAI or its protein and the occurrence and development of gastric cancer. In this study, we examined the dynamic relationship between SIPA1 (signal-induced proliferation-associated 1) gene and protein and the occurrence and development of gastric cancer. Correlation between expression of the protein encoded by SIPAI in gastric tumor tissues and angiogenesis was also determined.

\section{MATERIAL AND METHODS}

\section{Subjects}

Tumor tissue specimens used in the quantitative polymerase chain reaction (qPCR) and western blot analysis were surgically harvested from 40 gastric cancer patients, who were admitted in Linyi Central Hospital between March 2012 and May 2013. The patients included 23 males and 17 females with an average age of $54.3 \pm 2.4$ years (ranging from 42 to 72 years). Fresh gastric tumor tissue and tumor-adjacent normal tissue specimens (more than $5 \mathrm{~cm}$ away

Genetics and Molecular Research 16 (1): gmr16019271 
from the tumor tissue margin) were excised and stored in liquid nitrogen.

Specimens for immunohistochemical (IHC) staining were surgically harvested from 60 gastric cancer patients, who were admitted in our hospital between January 2009 and January 2011. The patients included 36 males and 24 females with an average age of 53.8 \pm 2.3 years (ranging from 40 to 70 years). Tumor-node-metastasis (TNM) staging classified 34 cases in stages I + II and 26 cases in stages III + IV. The degree of differentiation in the cancer cells was poor to moderate in 45 cases, and in 15 cases, cancer cells were welldifferentiated. Lymph node metastases were present in 50 of these cases and absent in the remaining 10 cases. The tumor diameter was $<5 \mathrm{~cm}$ in 35 cases and $\geq 5 \mathrm{~cm}$ in the remaining 25 cases. None of the patients had received any therapeutic intervention such as preoperative neoadjuvant chemotherapy, and after surgery, specimens of tumor tissues obtained from them were confirmed by pathological examination. In addition, tumor-adjacent normal tissue specimens (confirmed by pathological examination) were designated as controls and harvested from locations that were more than $5 \mathrm{~cm}$ away from the gastric tumor tissues in 40 gastric cancer patients. The patients included 24 males and 16 females with an average age of $54.1 \pm 2.5$ years (ranging from 41 to 71 years). This study was approved by the Ethics Committee at Linyi Central Hospital, and signed informed consent was obtained from all the study participants at the beginning of the study.

\section{Main reagents}

The reagents purchased were rabbit anti-human SIPA1 polyclonal antibodies (Tocan Biotechnology, Shanghai, China), IHC reagents (SangerBio, Shanghai, China), and radioimmunoprecipitation assay lysis buffer (Genshare Biological, Xi'an, China). The kits purchased were 3,3'-diaminobenzidine substrate kit (Solarbio Science \& Technology, Beijing, China), Trizol RNA kit (Wuhan Khayal Bio-Technology, Wuhan, China), reverse transcriptase kit (Beijing Protein Innovation, Beijing, China), and real-time quantitative PCR kit (Shanghai Xinfan Biological Technology, Shanghai, China). Specific primers were synthesized by Sangon Biotech (Shanghai, China). The polyvinylidene difluoride (PVDF) membrane was purchased from Shanghai Resun Trading, Shanghai, China.

\section{Methods}

\section{Real-time quantitative PCR}

Total RNA was extracted from gastric tumor tissues and tumor-adjacent normal tissues according to the Trizol kit manufacturer's protocol. The purity and concentration of total RNA were determined, and the integrity of total RNA was verified by $1 \%$ agarose gel electrophoresis. Reverse transcription was performed as per the Trizol kit manufacturer's protocol. The PCR mix was as follows: $10.0 \mu \mathrm{L}$ SYBR Premix Ex Taq, $0.4 \mu \mathrm{L}$ ROX reference dye, $0.4 \mu \mathrm{L}$ PCR forward primer $(10 \mu \mathrm{M}), 0.4 \mu \mathrm{L}$ PCR reverse primer $(10 \mu \mathrm{M}), 209.5 \mu \mathrm{L} \mathrm{dH}_{2} \mathrm{O}$, and $2 \mu \mathrm{L}$ DNA template. SIPA1 forward primer: 5'-TGCTGGCTACTACCGCAAATACTTC-3' SIPA1 reverse primer: 5'-ACGATGACGCGGTAGCTGTG-3' GAPDH (reference gene) forward primer: 5'-CTGCAGCATCTTCTCCTTCC-3' GAPDH reverse primer: 5'-CAAAGTTGTCATGGATGACC-3' PCR conditions (Brooks et al., 2010): Initial denaturation at $95^{\circ} \mathrm{C}$ for $30 \mathrm{~s}$, followed by 40 cycles of $95^{\circ} \mathrm{C}$ for $5 \mathrm{~s}$ and $60^{\circ} \mathrm{C}$ for $34 \mathrm{~s}$. Relative

Genetics and Molecular Research 16 (1): gmr16019271 
quantification was determined by calculating the threshold cycle $(\mathrm{Ct})$ values of each gene as follows: SIPA1 Ct - GAPDH Ct $=\Delta \mathrm{Ct}$; normal tissue $\Delta \mathrm{Ct}$ - tumor tissue $\Delta \mathrm{Ct}=\Delta \Delta \mathrm{Ct}$; and fold change $=2^{-\Delta \Delta C t}$.

\section{Western blot analysis}

Tissue samples were homogenized in $400 \mu \mathrm{L}$ lysis buffer on ice and centrifuged to obtain the supernatant. Protein concentrations of the samples were determined based on a bicinchroninic acid protein standard curve. After $1.5 \mathrm{~h}$ of sodium dodecyl sulfatepolyacrylamide gel electrophoresis, the separated sample proteins were transferred onto a PVDF membrane, incubated with primary antibody $(1: 1000)$ at $4{ }^{\circ} \mathrm{C}$ overnight and on the following day, with secondary antibody $(1: 3000)$ for $2 \mathrm{~h}$. The enhanced chemiluminescence substrate was added onto the PVDF membrane and the blots were allowed to develop for 5 min. An image of the membrane was then captured and analyzed (Gaudet et al., 2009; Ji et al., 2012).

\section{Streptavidin-peroxidase (SP) IHC}

SIPA1, VEGF-A, and FVIII in gastric tumor tissue and tumor-adjacent normal tissue specimens were detected by EnVision IHC staining, and the microvessel density (MVD) of FVIII-positive samples was calculated. IHC staining was performed according to the kit protocol and the resulting preparations were observed under the microscope (CX 41, Olympus, Japan).

\section{Evaluation criteria}

1) Semi-quantitative scoring was carried out using Berry's grading scale (Tang et al., 2016). Expression levels of SIPA1 and VEGF-A can be quantified based on positive staining in the cytoplasm of cells. The percentage of positive cells and the intensity of staining were determined for each sample. Expression levels were scored based on the color the cells displayed after staining: 0 point when the intensity of staining was similar to that of the negative controls, 1 point for light yellow staining, 2 points for brownish-yellow staining, and 3 points for brown staining. Scoring for the proportion of positively-stained cells in the total observed cells was done as follows: 1 point for $\leq 10 \%, 2$ points for $11-50 \%, 3$ points for $51-75 \%$, and 4 points for $>75 \%$. Grades for the samples were obtained by multiplying the two scores as follows: 0-3 points (-), 4-5 points (+), 6-7 points (++), and 8 points and above $(+++)$. A value of less than 3 points was graded as negative, while that of more than 3 points was graded as positive.

2) MVD was calculated based on Weidner's method (Park et al., 2016). FVIIIlabeled vascular endothelial cells stained brownish-yellow were used as positive standards. Positive endothelial cell clusters contributing to vascular lumen formation or vascular remodeling were regarded as one microvessel. Blood vessels with luminal area greater than 8 RBCs in diameter, a relatively thick muscle layer, or single positive cells were excluded. Three areas with the highest density of microvessels were selected. MVD for the areas was determined under a high-power field (200X), and the average MVD value was calculated. 


\section{Statistical analysis}

All data were analyzed using the SPSS 20.0 (IBM, City of New York, USA) statistical analysis software. Measured data are expressed as means \pm SD and were analyzed using the chisquare test, whereas enumerated data were analyzed using the paired sample t-test. Spearman's rank correlation was used to determine the correlation between various parameters. The results were considered statistically significant when $\mathrm{P}<0.05$.

\section{RESULTS}

\section{Detection by qPCR}

The presence of a single-peak melting curve (Figure 1) and an S-shaped amplification curve (Figure 2) indicated that there was no non-specific fluorescence during the reaction. The $\triangle \mathrm{Ct}$ values of SIPA1 mRNA in gastric tumor tissues and tumor-adjacent normal tissues were $4.62 \pm 0.65$ and $8.05 \pm 0.87$, respectively. The relative expression of SIPA1 mRNA was therefore significantly reduced in gastric tumor tissues $(\mathrm{P}<0.05)$.
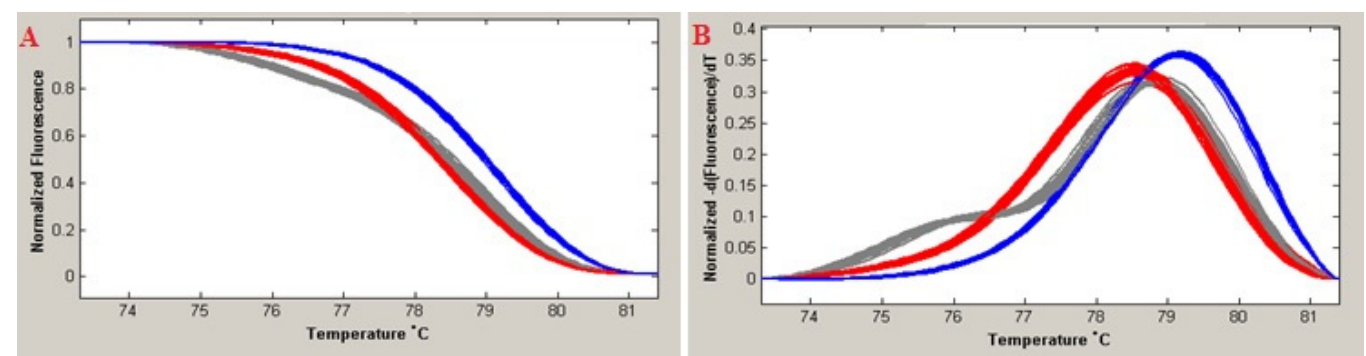

Figure 1. Single-peak melting curve.

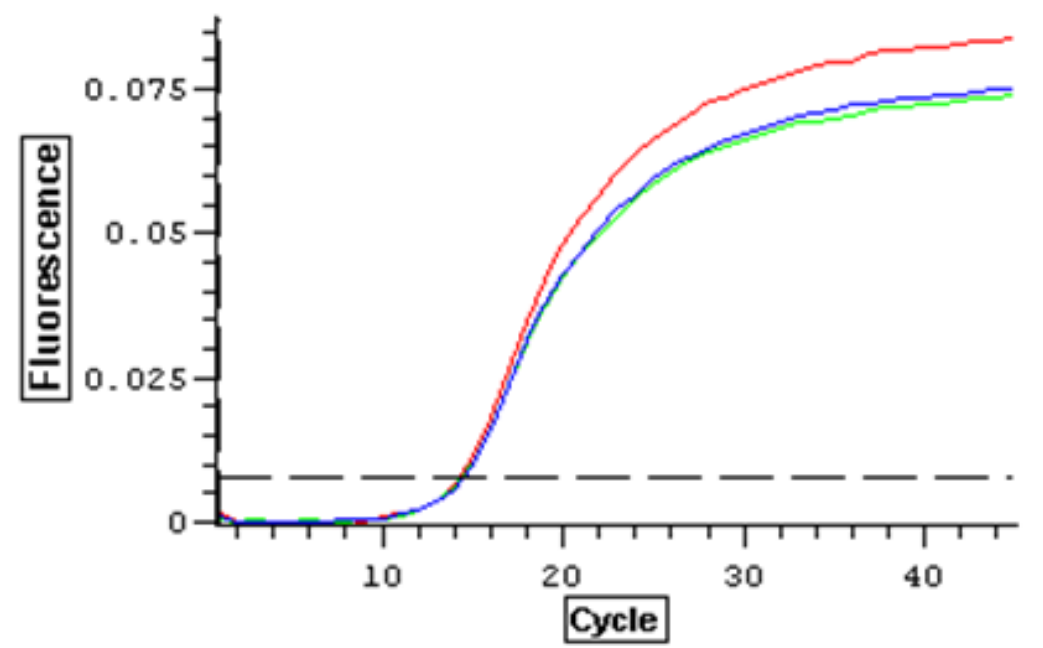

Figure 2. S-shaped amplification curve. 


\section{Detection by western blot}

Western blot results revealed that the expression of SIPA1 in the 40 gastric tumor tissue samples $(0.3043 \pm 0.1062)$ was significantly lower than that in the tumor-adjacent normal tissues $(0.5423 \pm 0.0682, \mathrm{P}<0.05)$ (Figure 3).

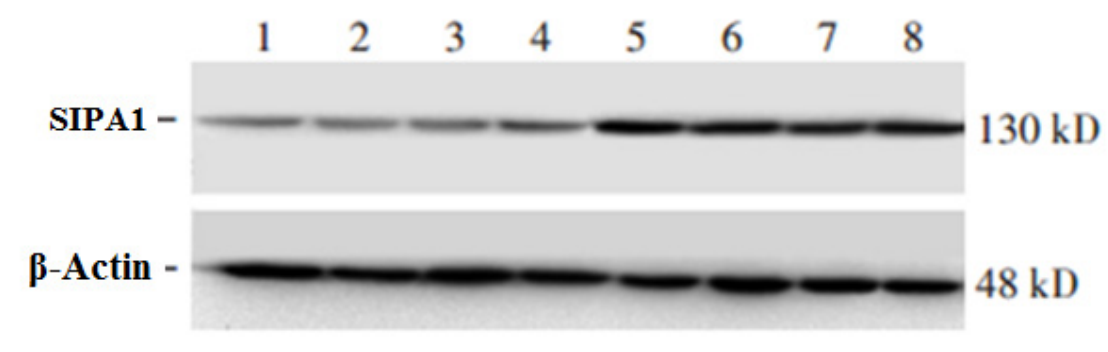

1-4: Gastric tumor tissues 5-8: Tumor-adjacent normal tissues

Figure 3. Detection of expression of SIPA1 in gastric tumor tissues by western blot.

\section{Detection by IHC}

Positive staining of SIPA1 and VEGF-A was displayed as brownish-yellow particles located in the cytoplasm (Figure 4). SIPA1 expression, as indicated by the positive staining rate, in gastric tumor tissues $(48.3 \%)$ was significantly lower than that in tumor-adjacent normal tissues $(65.0 \%)(\mathrm{P}<0.05)$ (Table 1). Similarly, VEGF-A expression, as indicated by the positive staining rate, in gastric tumor tissues $(36.7 \%)$ was also significantly higher than that in tumor-adjacent normal tissues $(2.5 \%, \mathrm{P}<0.05)$ (Table 2$)$.

Table 1. SIPA1 expression in gastric cancer tissues and tumor-adjacent normal tissues.
\begin{tabular}{l|c|c|c|c|c}
\hline \multirow{2}{*}{ Specimen source } & $\mathrm{N}$ & + & ++ & +++ & Positive staining rate (\%) \\
\cline { 2 - 5 } & 100 & 14 & 18 & 23 & \\
\hline Gastric tumor tissue & 60 & 7 & 9 & 13 & 48.3 \\
\hline Tumor-adjacent normal tissue & 40 & 7 & 9 & 10 & 65.0 \\
\hline
\end{tabular}

Table 2. VEGF-A expression in gastric cancer tissues and tumor-adjacent normal tissues (number of cases).

\begin{tabular}{l|c|c|c|c|c}
\hline Specimen source & $\mathrm{N}$ & + & ++ & ++ & Positive staining rate (\%) \\
\hline Gastric tumor tissue & 60 & 4 & 6 & 12 & 36.7 \\
\hline Tumor-adjacent normal tissue & 40 & 1 & 0 & 0 & 2.5 \\
\hline
\end{tabular}

\section{Relationship between SIPA1 and VEGF-A expression and clinical-pathological features of gastric cancer in patients}

SIPA1 and VEGF-A expression, indicated by positive staining rates, in gastric cancer tissues were found to be correlated with the degree of differentiation, lymph node metastases, and clinical grading $(\mathrm{P}<0.05)$ and not with sex, age, or tumor size $(\mathrm{P}>0.05)$ (Table 3$)$.

Genetics and Molecular Research 16 (1): gmr16019271 


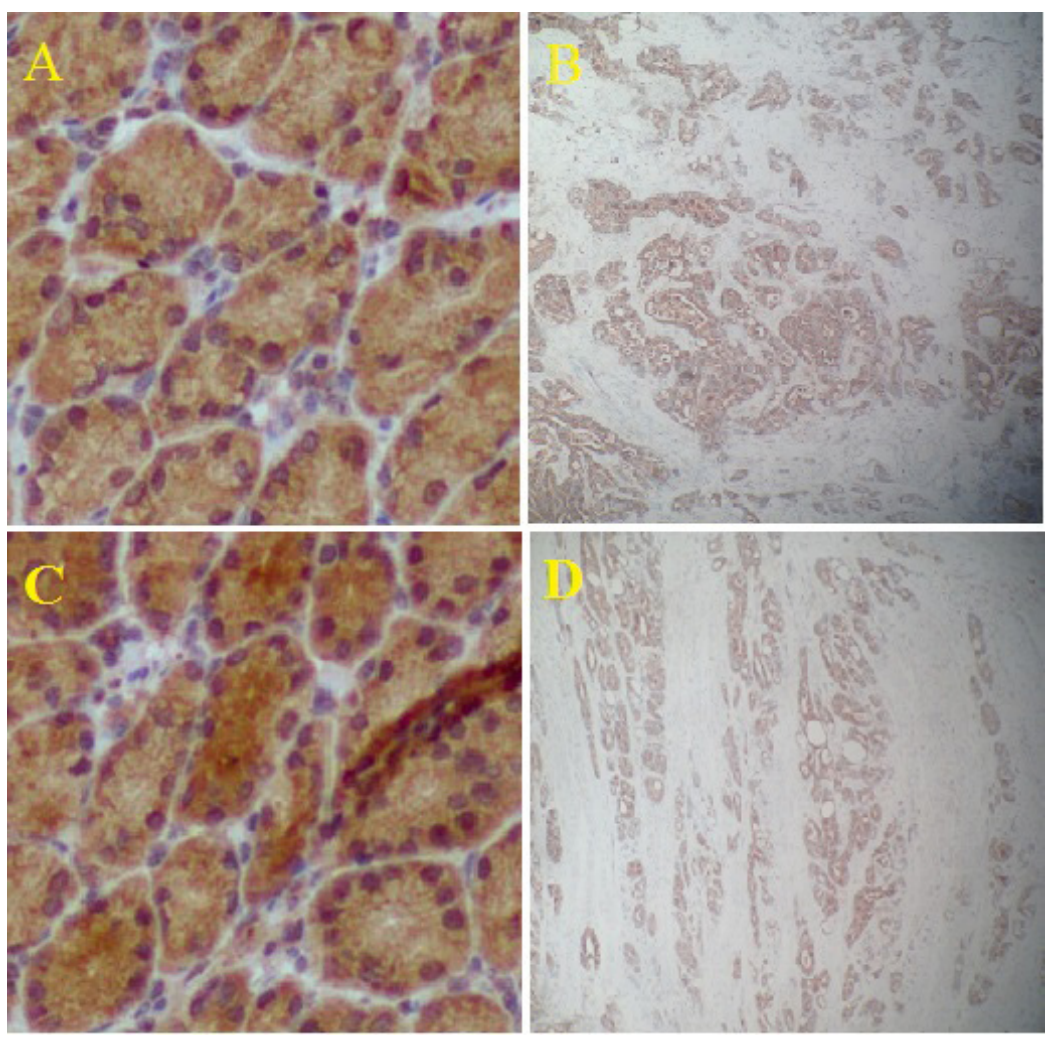

Figure 4. SIPA1 and VEGF-A expression in gastric tumor tissues and tumor-adjacent normal tissue (200X) (A. SIPA1 expression in tumor-adjacent normal tissue; B. SIPA1 expression in gastric tumor tissues; C. VEGF-A expression in tumor-adjacent normal tissue; D. VEGF-A expression in gastric tumor tissues).

Table 3. Relationship between SIPA1 and VEGF-A expression and clinical-pathological features of gastric cancer in patients.

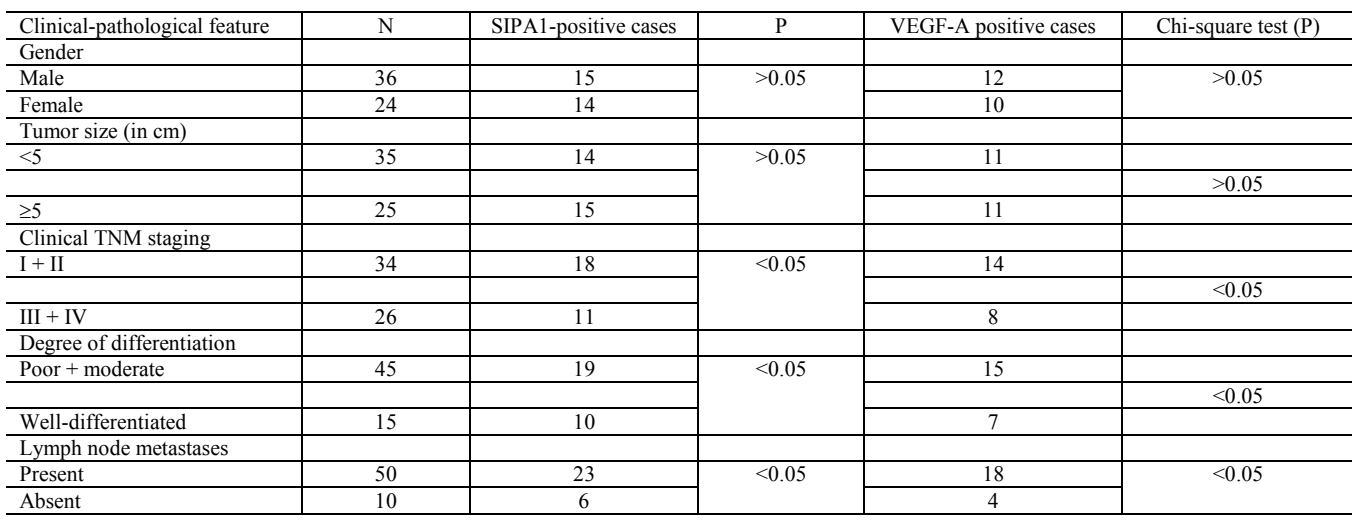

Genetics and Molecular Research 16 (1): gmr16019271 


\section{Relationship between SIPA1 and VEGF-A expression and MVD}

The MVD value of gastric tumor tissues that stained positive for SIPA1 (57.4 $\pm 9.3)$ was significantly higher than that of tumor-adjacent normal tissues $(41.2 \pm 5.7, \mathrm{P}<$ 0.05 ) (Figure 5). Spearman's rank correlation analysis indicated that SIPA1 expression was negatively correlated with VEGF-A expression in gastric tumor tissues $(\mathrm{r}=-0.736, \mathrm{P}<0.05)$.

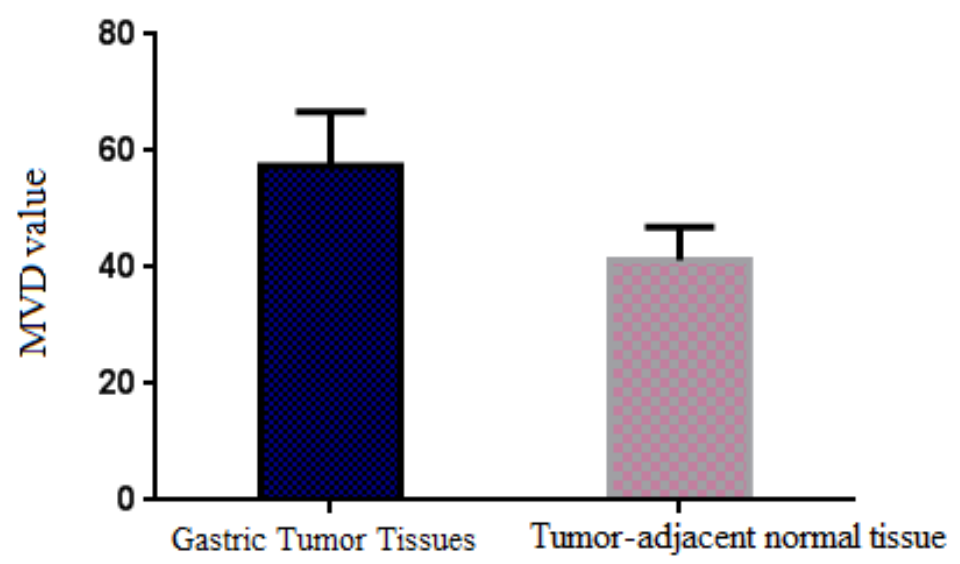

Figure 5. Comparison of MVD values of gastric cancer tissues with tumor-adjacent normal tissues that stained positive for SIPA1.

\section{DISCUSSION}

SIPA1 is one of the key candidate genes involved in efficient tumor metastasis. Previous studies (Gdowicz-Kłosok et al., 2015; Hunter, 2015; Sun et al., 2015; Wang et al., 2015; Marfà et al., 2016; Nagasawa et al., 2016) have demonstrated that SIPA1 is primarily expressed in lymphoid and hematopoietic tissues, and studies on hematological diseases have already confirmed the important role of SIPA1 in hematological malignancies. With the progress of SIPA1 research, it has been found that SIPA1 expression is upregulated in pathological tissues of patients with prostate or breast cancers, and can induce the manifestation, proliferation, and invasion of these cancer cells (Park et al., 2005; Uechi et al., 2009; Ugenskienè et al., 2016). On the other hand, the study by Budhu et al. (2005) demonstrated that SIPA1 expression was downregulated in primary hepatocellular carcinoma (HCC) tissues. Yet another study (Kong et al., 2016) that examined SIPA1 expression in HCC, tumor-adjacent, and normal tissues using the IHC SP method found that SIPA1 expression, indicated by the protein's positive staining rate, was significantly lower in tumor tissues as compared to that in other tissues. However, in HCC samples with venous invasion, the positive staining rate of SIPA1 was markedly reduced in tumor-adjacent tissues. In addition, patients with low SIPA1 positive staining rate in tumoradjacent tissues have relatively higher post-surgery disease recurrence and shorter survival rates. SIPA1, therefore, functions as a tumor-suppressor gene in $\mathrm{HCC}$ and plays an important role in inhibiting the post-surgery recurrence and metastasis of HCC. In this study, we found that the relative expression of SIPA1 mRNA in gastric cancer tissues was significantly lower than that in tumor-adjacent normal tissues $(\mathrm{P}<0.05)$. However, the positive staining rate of SIPA1 in gastric tumor tissues $(55 \%)$ was markedly higher than that in tumor-adjacent tissues 
$(2.5 \%, \mathrm{P}<0.05)$. Moreover, the positive staining rates of SIPA1 and VEGF-A in tumor tissues of gastric cancer patients correlated with the degree of differentiation, lymph node metastases, and clinical grading $(\mathrm{P}<0.05)$ and not with sex, age, or tumor size $(\mathrm{P}>0.05)$. Since the expression levels of both SIPA1 mRNA as well as the protein were significantly lower in gastric tumor tissues than in tumor-adjacent normal tissues, our findings indicate that SIPA1 acts as a tumor suppressor gene in gastric cancer.

Tumor metastasis is a complex process that involves multiple steps and factors. In particular, angiogenesis and venous invasion are not only the critical steps in this process but also independent risk factors that affect the post-surgical survival of cancer patients. VEGF-A is a member of the VEGF family, and has been confirmed to be a key regulator of angiogenesis. Since the number of newly formed blood vessels within a tumor is usually measured by MVD, both MVD and VEGF-A are good indicators of angiogenesis (Thielemann et al., 2008; Sanaat et al., 2014; Della-Morte et al., 2015). However, the correlation between SIPA1 expression and angiogenesis in gastric tumor tissues was unclear so far. Our results indicated that the positive staining rates of SIPA1 (48.3\%) and VEGF-A (36.7\%) were significantly lower and higher, respectively, in gastric tumor tissues than in tumor-adjacent normal tissues (65.0 and $2.5 \%$, respectively) in gastric cancer patients $(\mathrm{P}<0.05)$. These rates correlated with the degree of differentiation, lymph node metastases, and clinical grading $(\mathrm{P}<0.05)$, and not with sex, age, or tumor size $(\mathrm{P}>0.05)$. The MVD value of gastric tumor tissues that were positive for SIPA1 expression $(57.4 \pm 9.3)$ was also markedly higher than that of tumor-adjacent normal tissues $(41.2 \pm 5.7, \mathrm{P}<0.05)$. Furthermore, Spearman's rank correlation analysis showed that SIPA1 expression was negatively correlated with VEGF-A expression in gastric tumor tissues $(r=-0.736, P<0.05)$. These results indicate that SIPA1 gene and protein expression may play an important role in the invasion, development, and metastasis of gastric cancer, and that low expression of SIPA1 in gastric tumor tissues may accelerate the occurrence and progression of gastric cancer by promoting VEGF-A expression to increase vascular density in the body. A limitation of this study is the relatively small sample size that needs to be expanded in future studies. In addition, the present study is a retrospective study; therefore, we recommend conducting prospective studies that can comprehensively explore the relationship between SIPA1 gene and protein expression and gastric cancer in the future.

\section{Conflicts of interest}

The authors declare no conflict of interest.

\section{ACKNOWLEDGMENTS}

The authors thank all the patients and family members for their participation. Research supported by the Linyi Central Hospital.

\section{REFERENCES}

Brooks R, Kizer N, Nguyen L, Jaishuen A, et al. (2010). Polymorphisms in MMP9 and SIPA1 are associated with increased risk of nodal metastases in early-stage cervical cancer. Gynecol. Oncol. 116: 539-543. http://dx.doi.org/10.1016/j. ygyno.2009.09.037

Budhu AS, Zipser B, Forgues M, Ye QH, et al. (2005). The molecular signature of metastases of human hepatocellular carcinoma. Oncology 69 (Suppl 1): 23-27. http://dx.doi.org/10.1159/000086628

Genetics and Molecular Research 16 (1): gmr16019271 
Della-Morte D, Riondino S, Ferroni P, Palmirotta R, et al. (2015). Impact of VEGF gene polymorphisms in elderly cancer patients: clinical outcome and toxicity. Pharmacogenomics 16: 61-78. http://dx.doi.org/10.2217/pgs.14.136

Gaudet MM, Hunter K, Pharoah P, Dunning AM, et al. (2009). Genetic variation in SIPA1 in relation to breast cancer risk and survival after breast cancer diagnosis. Int. J. Cancer 124: 1716-1720. http://dx.doi.org/10.1002/ijc.23919

Gdowicz-Kłosok A, Giglok M, Drosik A, Suwiński R, et al. (2015). The SIPA1 -313A>G polymorphism is associated with prognosis in inoperable non-small cell lung cancer. Tumour Biol. 36: 1273-1278. http://dx.doi.org/10.1007/ $\underline{\text { s13277-014-2753-8 }}$

Hamashima C, Ogoshi K, Narisawa R, Kishi T, et al. (2015). Impact of endoscopic screening on mortality reduction from gastric cancer. World J. Gastroenterol. 21: 2460-2466. http://dx.doi.org/10.3748/wjg.v21.i8.2460

Hsieh SM, Smith RA, Lintell NA, Hunter KW, et al. (2009). Polymorphisms of the SIPA1 gene and sporadic breast cancer susceptibility. BMC Cancer 9: 331. http://dx.doi.org/10.1186/1471-2407-9-331

Hunter K (2015). The role of individual inheritance in tumor progression and metastasis. J. Mol. Med. (Berl.) 93: 719-725. http://dx.doi.org/10.1007/s00109-015-1299-6

Ji K, Ye L, Toms AM, Hargest R, et al. (2012). Expression of signal-induced proliferation-associated gene 1 (SIPA1), a RapGTPase-activating protein, is increased in colorectal cancer and has diverse effects on functions of colorectal cancer cells. Cancer Genomics Proteomics 9: 321-327.

Kim JG and Zhang Y (2013). Molecular targeted therapy for advanced gastric cancer. Korean J. Intern. Med. 28: 149-155. http://dx.doi.org/10.3904/kjim.2013.28.2.149

Kong LM, Yao L, Lu N, Dong YL, et al. (2016). Interaction of KLF6 and Sp1 regulates basigin-2 expression mediated proliferation, invasion and metastasis in hepatocellular carcinoma. Oncotarget 7: 27975-27987.

Li DN, Wang L, Wang L, Li S, et al. (2016). Expression of inhibitor of differentiation-1 and its effects on angiogenesis in gastric cancer. Cancer Biother. Radiopharm. 31: 233-237. http://dx.doi.org/10.1089/cbr.2016.2043

Marfà S, Morales-Ruiz M, Oró D, Ribera J, et al. (2016). Sipa111 is an early biomarker of liver fibrosis in CCl4-treated rats. Biol. Open 5: 858-865. http://dx.doi.org/10.1242/bio.018887

Nadauld LD and Ford JM (2013). Molecular profiling of gastric cancer: toward personalized cancer medicine. J. Clin. Oncol. 31: 838-839. http://dx.doi.org/10.1200/JCO.2012.47.1714

Nagasawa A, Koike T, Okamoto T, Namura O, et al. (2016). Surgical resection for solitary myocardial metastasis of gastric cancer. Ann. Thorac. Surg. 101: 1978-1980. http://dx.doi.org/10.1016/j.athoracsur.2015.06.108

Park WC, Kim HR, Kang DB, Ryu JS, et al. (2016). Comparative expression patterns and diagnostic efficacies of SR splicing factors and HNRNPA1 in gastric and colorectal cancer. BMC Cancer 16: 358. http://dx.doi.org/10.1186/ $\underline{\mathrm{s} 12885-016-2387-\mathrm{X}}$

Park YG, Zhao X, Lesueur F, Lowy DR, et al. (2005). Sipa1 is a candidate for underlying the metastasis efficiency modifier locus Mtes1. Nat. Genet. 37: 1055-1062. http://dx.doi.org/10.1038/ng1635

Sanaat Z, Khalili R, Almasi S, Aliparasti MR, et al. (2014). Does chemotherapy change expression of VEGF A\&C and MVD in acute myeloid leukemia? Int. J. Hematol. Oncol. Stem Cell Res. 8: 24-29.

Süllner J, Lattrich C, Häring J, Görse R, et al. (2012). A polymorphism in the nuclear receptor coactivator 7 gene and breast cancer susceptibility. Oncol. Lett. 3: 131-134.

Sun X, Sun Z, Zhu Z, Li C, et al. (2015). Expression of SIP1 is strongly correlated with LDHA and shows a significantly poor outcome in gastric cancer. Tumour Biol. 36: 7521-7530. http://dx.doi.org/10.1007/s13277-015-3470-7

Tanaka H, Tamura A, Sekai M, Hamazaki Y, et al. (2011). Increased c-Myc activity and DNA damage in hematopoietic progenitors precede myeloproliferative disease in Spa-1-deficiency. Cancer Sci. 102: 784-791. http://dx.doi. org/10.1111/j.1349-7006.2011.01850.x

Tang Z, Ma J, Zhang W, Gong C, et al. (2016). The role of prion protein expression in predicting gastric cancer prognosis. J. Cancer 7: 984-990. http://dx.doi.org/10.7150/jca.14237

Thielemann A, Kopczyński Z, Filas V, Breborowicz J, et al. (2008). The determination of VEGF and MVD, among patients with primary breast cancer. Pathol. Oncol. Res. 14: 137-144. http://dx.doi.org/10.1007/s12253-008-9040-1

Uechi Y, Bayarjargal M, Umikawa M, Oshiro M, et al. (2009). Rap2 function requires palmitoylation and recycling endosome localization. Biochem. Biophys. Res. Commun. 378: 732-737. http://dx.doi.org/10.1016/j.bbrc.2008.11.107

Ugenskienė R, Myrzaliyeva D, Jankauskaitė R, Gedminaite J, et al. (2016). The contribution of SIPA1 and RRP1B germline polymorphisms to breast cancer phenotype, lymph node status and survival in a group of Lithuanian young breast cancer patients. Biomarkers 21: 363-370. http://dx.doi.org/10.3109/1354750X.2016.1141989

Wang CY, Hua L, Yao KH, Chen JT, et al. (2015). Long non-coding RNA CCAT2 is up-regulated in gastric cancer and associated with poor prognosis. Int. J. Clin. Exp. Pathol. 8: 779-785.

Genetics and Molecular Research 16 (1): gmr16019271 